\title{
Use of de-oiled groundnut cake flour as an alternate source of nutrition
}

Diksha Srivastava, A. N. Mathur and Mrunal K. Shirshat

Received : 02.01.2018; Revised : 23.02.2018; Accepted : 04.03.2018

See end of the Paper for authors' affiliation

Correspondence to :

Diksha Srivastava Pacific Academy of Higher Education and Research

University, Udaipur (Rajasthan) India Email : dkshme@gmail.com
ABSTRACT : De-oiled cake is a rich source of protein for vegetarians the utilization of meal or defatted meal into food products could be an excellent vehicle for enhancing the consumption of groundnut protein in the diets of malnourished people in developing countries. Groundnut flour produced from cake blends easily and enhances or enriches the nutritive value of wheat and other flour. The study was conducted in Pacific College of Pharmacy, PAHER University, Udaipur. Value added products namely Laddoo, Chutney powder, Seviyan, fryums and biscuits were developed and their nutritional richness and organoleptic evaluation was done. All the products were well accepted by the people and can be marketed and produced. This proves that these products can be used for substituting fat rich and adulterated low quality food products that are often being marketed and consumed.

- KEY WORDS : Groundnut, De-oiled cake flour, Value added products, Protein rich

- HOW TO CITE THIS PAPER : Srivastava, Diksha, Mathur, A.N. and Shirshat, Mrunal K.(2018). Use of de-oiled groundnut cake flour as an alternate source of nutrition. Internat. J. Agric. Engg., 11(1) : 150-152, DOI: 10.15740/HAS/IJAE/11.1/150-152. 